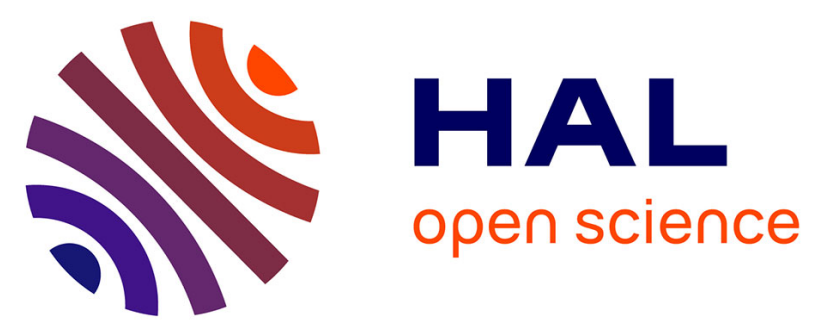

\title{
Evaluation of a real-time two-step RT-PCR assay for quantitation of Chronic bee paralysis virus (CBPV) genome in experimentally-infected bee tissues and in life stages of a symptomatic colony.
}

Philippe Blanchard, Magali Ribière, Olivier Celle, Perrine Lallemand, Frank Schurr, Violaine Olivier, Anne Laure Iscache, Jean Paul Faucon

\section{To cite this version:}

Philippe Blanchard, Magali Ribière, Olivier Celle, Perrine Lallemand, Frank Schurr, et al.. Evaluation of a real-time two-step RT-PCR assay for quantitation of Chronic bee paralysis virus (CBPV) genome in experimentally-infected bee tissues and in life stages of a symptomatic colony.. Journal of Virological Methods, 2007, 141 (1), pp.7-13. 10.1016/j.jviromet.2006.11.021 . anses-00414768

\section{HAL Id: anses-00414768}

\section{https://hal-anses.archives-ouvertes.fr/anses-00414768}

Submitted on 11 Sep 2009

HAL is a multi-disciplinary open access archive for the deposit and dissemination of scientific research documents, whether they are published or not. The documents may come from teaching and research institutions in France or abroad, or from public or private research centers.
L'archive ouverte pluridisciplinaire HAL, est destinée au dépôt et à la diffusion de documents scientifiques de niveau recherche, publiés ou non, émanant des établissements d'enseignement et de recherche français ou étrangers, des laboratoires publics ou privés. 
1 EVALUATION OF A REAL-TIME TWO-STEP RT-PCR ASSAY FOR

2 QUANTITATION OF CHRONIC BEE PARALYSIS VIRUS (CBPV)

3 GENOME IN EXPERIMENTALLY-INFECTED BEE TISSUES AND IN

4 LIFE STAGES OF A SYMPTOMATIC COLONY.

5

6 Philippe Blanchard*, Magali Ribière, Olivier Celle, Perrine Lallemand,

7 Frank Schurr, Violaine Olivier, Anne Laure Iscache, Jean Paul

8 Faucon.

9

10 Agence Française de Sécurité Sanitaire des Aliments (AFSSA), Les Templiers, Route 11 des Chappes, BP 111, 06902 Sophia Antipolis, France.

12

$17{ }^{*}$ Corresponding author

18 Mailing address: Blanchard Philippe, AFSSA Sophia-Antipolis, Unité Pathologie de

19 I'Abeille, Les Templiers, BP 111, Fr - 06902 Sophia Antipolis

20 Telephone number: $+33(0) 492.943 .726$

21 Fax number: $+33(0) 492.943 .701$

22 e-mail: p.blanchard@afssa.fr 


\section{Abstract}

24 A two-step real-time RT-PCR assay, based on TaqMan technology using a fluorescent 25 probe (FAM-TAMRA) was developed to quantify Chronic bee paralysis virus (CBPV) 26 genome in bee samples. Standard curves obtained from a CBPV control RNA and from a 27 plasmid containing a partial sequence of CBPV showed that this assay provided linear detection over a 7-log range $\left(R^{2}>0.99\right)$ with a limit of detection of 100 copies, and reliable

29 inter-assay and intra-assay reproducibility. Standardisation including RNA purification and 30 cDNAs synthesis was also validated.

31 The CBPV TaqMan methodology was first evaluated by quantifying the CBPV genomic Ioad in bee samples from an experimental infection obtained by topical application. Up to

$331.9 \times 10^{10} \mathrm{CBPV}$ copies per segment of insect body (head, thorax and abdomen) were 34 revealed whereas a lower CBPV genomic load was detected in dissected organs such as 35 mandibular and hypopharyngeal glands, brain and alimentary canal (up to $7.2 \times 10^{6}$ 36 CBPV copies). The CBPV genomic loads in different categories of bees from a hive 37 presenting the trembling symptoms typical of Chronic paralysis were then quantified. 38 Significantly higher CBPV loads were found in guard, symptomatic and dead bees (up to

$391.9 \times 10^{13}$ CBPV copies) than in forager, drones and house bees (up to $3.4 \times 10^{6} \mathrm{CBPV}$ 40 copies). The results obtained for symptomatic or dead bees support the correlation 41 between high CBPV genomic load and pathology expression. Moreover, the high CBPV 42 genomic load revealed in guard bees highlights the possible pivotal role played by this 43 category of bees in CBPV infection.

Keywords: Chronic bee paralysis virus (CBPV), Real-time PCR, Quantitation, 46 Infection dynamics, Apis mellifera. 


\section{1. Introduction}

48 Chronic bee paralysis virus (CBPV) is classified as a multipartite, positive-strand RNA 49 virus. Its family and genus are currently unassigned. CBPV was first isolated in 1963 50 (Bailey et al., 1963) and characterized in 1968 (Bailey et al., 1968). CBPV is the 51 aetiological agent of an infectious and contagious disease of adult honey bees (Apis mellifera L.) known as Chronic paralysis (Ball \& Bailey, 1997). Chronic paralysis is 53 characterized by clusters of trembling, flightless, crawling bees and by individual black, 54 hairless bees standing at the hive entrance (Bailey et al., 1983). This pathology is known 55 to induce significant losses in honey bee colonies (Bailey et al., 1963; Ball \& Bailey, 1997; 56 Allen \& Ball, 1996). Current diagnosis of the clinical disease is based on an AGID test 57 (Agarose Gel ImmunoDiffusion) (Ribière et al., 2000; Ball, 1999), recently complemented by RT-PCR (Ribière et al., 2002), which has improved the detection sensitivity of CBPV, even in asymptomatic hives. Although these techniques are used to characterize the CBPV status of hives, they cannot estimate the level of CBPV infection. The quantitation of CBPV should permit a better understanding of the viral infection both in individual bees and in the hive.

Real-time RT-PCR detection methods have been recently developed for the detection and quantitation of bee viruses (Chen et al., 2005b; Tentcheva et al., 2006; Chantawannakul et al., 2006). This paper describes a real-time two-step RT-PCR based on the TaqMan methodology (Heid et al., 1996; Holland et al., 1991; Livak et al., 1995) to quantify CBPV. Standard curves from a viral RNA control and a plasmid containing a partial sequence of CBPV genome were used to obtain an absolute quantitation of CBPV. The specificity and reproducibility of the method were validated from the standard DNA curve. An experimental infection obtained by contact with purified virus was used to evaluate the method and estimate the CBPV distribution in bee tissues. The method was then applied to assess virus distribution in different categories of bees sampled from a colony with Chronic paralysis. 


\section{$74 \quad$ 2. Materials and methods}

76 2.1 Sample preparation, RNA extraction and cDNA synthesis

77 Adult bees were individually crushed in $1 \mathrm{ml}$ of $0.01 \mathrm{M}$ phosphate buffer $\mathrm{pH} 6.8$ in a 78 tenbroeck grinder (Wheaton Sciences Products). The grinder was machine washed after 79 treating with RNA and DNA decontaminant (LTK008). Hemolymph samples were 80 collected by puncturing the intersegmental membrane at neck level, before organs 81 dissection, using a Pasteur pipette (Fluri et al., 1982) and diluted ten fold with phosphate buffer. Body segments (head, thorax, abdomen), organs dissected under binocular 83 magnifier (mandibular and hypopharyngeal glands, brain, alimentary canal) and pooled brood samples (eggs, larvae, pupae) were washed once with phosphate buffer, then crushed in a microcentrifuge tube using a piston pellet (Eppendorf) in phosphate buffer. The homogenate was first centrifuged at $8000 \mathrm{~g}$ for $10 \mathrm{~min}$. The supernatant was recovered, centrifuged again at $8000 \mathrm{~g}$ for $10 \mathrm{~min}$. Two hundred $\mu \mathrm{l}$ of the final supernatant were then subjected to RNA extraction using the "High Pure Viral RNA Kit" (Roche diagnosis) according to the manufacturer's recommendations. First strand cDNA was synthesized from extracted RNA as described by Ribière et al. (2002). Five $\mu$ l of the

91 cDNA were then used as template for the CBPV TaqMan PCR.

The primers and probe were designed by Sigma-Proligo. The chosen primer set amplifies a $101 \mathrm{bp}$ fragment and is located in the putative viral RNA polymerase gene region of CBPV (Ribière et al., 2002). The forward primer was 5'-CGCAAGTACGCCTTGATAAAGAAC and the reverse primer 99 was 5'-ACTACTAGAAACTCGTCGCTTCG. The TaqMan probe was 5'100 TCAAGAACGAGACCACCGCCAAGTTC, labelled with the fluorescent reporter dye FAM 
101 (6-carboxyfluorescein) at the 5' end and with the fluorescent quencher dye TAMRA at the 102 3' end.

103 The Platinum ${ }^{\circledast}$ Quantitative PCR SuperMix-UDG (PQM 2X, Invitrogen) was used for the 104 amplification reaction of the TaqMan PCR. The PCR reaction contained 1X PQM, $300 \mathrm{nM}$ 105 of each primer, $200 \mathrm{nM}$ of the probe, $2 \mathrm{mM}$ of $\mathrm{MgCl}_{2}$ (final $\mathrm{MgCl}_{2}$ concentration of $5 \mathrm{mM}$ ) 106 and $5 \mu$ l of standard template (RNA control or plasmid) or cDNAs in a $25 \mu$ l total reaction 107 volume. The reaction was performed in a $25 \mu$ s SmartCycler ${ }^{\circledR}$ Tube (Cepheid, 108 Instrumentation Laboratory). The thermal cycling conditions were $2 \mathrm{~min}$ at $50^{\circ} \mathrm{C}$ (action of 109 uracil-N-glycosylase (UDG) to degrade any carryover DNA amplified from previous 110 reactions), 2 min at $95^{\circ} \mathrm{C}$ (activation of Platinum Taq DNA polymerase and degradation of 111 UDG), followed by 40 cycles consisting of denaturing at $95^{\circ} \mathrm{C}$ for $10 \mathrm{~s}$, annealing at $50^{\circ} \mathrm{C}$ 112 for $10 \mathrm{~s}$ and extension at $72^{\circ} \mathrm{C}$ for $20 \mathrm{~s}$. The SmartCycler ${ }^{\circledR} \|$ System (Cepheid) was used 113 for amplification and detection.

1152.3 Preparation of viral RNA and plasmid DNA standards for calibration of the CBPV 116 TaqMan PCR assay

117 A viral RNA control was obtained from the heads of sick bees, experimentally infected by 118 inoculation as previously described by Ribière et al (2000). Based on the extracted RNA 119 concentration determined by UV spectrometry, homogenates were then diluted to obtain $120 \quad 0.8 \times 10^{7}$ to 0.8 RNA copies per $\mu$ l. Two hundred $\mu$ l of each dilution were subjected to 121 RNA extraction and cDNA synthesis. A RNA standard curve for the range of $10^{8}$ to 10 122 RNA copies per reaction was generated by analysing $5 \mu$ of each cDNA sample by 123 TaqMan PCR.

124 A standard DNA curve was generated with a $3.82 \mathrm{~kb}$ plasmid, obtained by cloning a 800 125 bp PCR fragment located in the putative viral RNA polymerase gene of CBPV into the 126 PGEM $^{\circledast}$-T Easy vector (Promega). Based on the DNA concentration determined by UV 127 spectrometry, stock solutions were prepared from serial dilutions containing $0.2 \times 10^{8}$ to 2 
128 DNA copies per $\mu \mathrm{l}$ in TE buffer. A standard DNA curve for the range of $10^{8}$ to 10 DNA

129 copies per reaction was generated by analysing $5 \mu \mathrm{l}$ of each dilution by TaqMan PCR.

130 In both cases, the homogenate obtained from the heads of infected bees described

131 above, was subjected to RNA extraction and cDNA synthesis and used as a positive

132 control. A negative control (template-free) was included.

$134 \quad 2.4$ Evaluation of the method

135 The two standard curves (viral RNA and plasmid DNA) were compared for the

136 efficiencies, coefficients of correlation and results obtained for the positive control.

137 The limit of detection of the CBPV TaqMan PCR was compared with that of the

138 qualitative PCR test previously described by Ribière et al. (2002), by testing the viral RNA

139 and plasmid DNA standard prepared in dilution as detailed above. The primers were

140 CBPV1: AGTTGTCATGGTTAACAGGATACGAG and CBPV2: TCTAATCTTAGCACGAA

141 AGCCGAG. After conventional PCR, the amplified products (455 bp) were analysed in an

142 ethidium bromide-stained $1.5 \%$ agarose gel.

143 The specificity of the CBPV TaqMan PCR was assessed by testing CDNAs obtained from

144 ABPV (Acute bee paralysis virus), SBV (Sacbrood virus), BQCV (Black queen cell virus)

145 and DWV (Deformed wing virus) samples, checked as highly positive by serial dilution in

146 the respective specific RT-PCR tests. The primers used in the RT-PCR tests either had

147 been previously described for ABPV (Bakonyi et al., 2002) and SBV (Grabensteiner et al.,

148 2001), or designed in our lab for BQCV (BQCV 3: GGTGCAAGTCTCTTCCTAG and

149 BQCV 4: AATAACCTGAAAGGCCAAGAG) and DWV (DWV3: GGTCCGCGGCTAAGAT

150 TGTA and DWV4: CGGCTGTTTGATGGAAGAAGTT).

151 The reproducibility of the CBPV TaqMan PCR assay was demonstrated by evaluating the

152 intra- and inter-assay variability of the $C_{T}$ values obtained after amplification of 10-fold

153 serial dilutions of the plasmid DNA standard ranging from $10^{1}$ to $10^{8}$ copies per reaction.

154 Intra-assay reproducibility was evaluated by analysing three replicates of the 10 -fold

155 serial dilutions of plasmid during the same experiment. Inter-assay reproducibility was 
156 estimated by testing serial dilutions of the same standard in ten independent

157 experiments, performed on different days.

158 The efficiency of RNA purification and cDNA synthesis was monitored by testing the 159 positive control (RNA purification followed by cDNA synthesis) ten times and measuring 160 the variability of the $C_{T}$ values. In addition, 10 pooled bees from a field sample were 161 crushed, divided into 10 sub-samples, and then tested ten times (RNA purification 162 followed by cDNA synthesis) to determine sample preparation efficiency. Finally, the 163 effect of crushing was evaluated by homogenizing healthy bees for half the normal 164 homogenization time, checking the negativity, loading with diluted purified virus and then 165 completing the homogenization. Ten sub-samples were tested (RNA purification followed 166 by cDNA synthesis) to assess the effect of homogenization on the virus.

1682.5 Validation of the CBPV TaqMan PCR method on experimentally- and naturally169 infected bees

170 First, paralysed bees were obtained from an experimental model based on bee infection 171 by topical application as described by Bailey et al (1983). Briefly, bees anaesthetized with 172 carbon dioxide, were infected by contact with $3 \mu$ of a one thousand fold diluted viral 173 purification on the shaved thorax (Group 1). The CBPV genomic load of this inoculum 174 was determined. Negative controls were obtained by replacing the inoculum with 175 physiological solution (Group 2). Trembling symptoms and mortalities were recorded daily 176 until day 12 post-infection. Hemolymph samples were collected, at day 8 post-infection, 177 from bees of both groups. The out-flowing hemolymph from 20 bees was pooled in chilled 178 tubes and diluted ten fold with phosphate buffer. Four bees from each group were killed 179 between days 8 and 9 post-contact and tissues of mandibular and hypopharyngeal 180 glands, brain and alimentary canal were dissected. At the same time, the head, thorax 181 and abdomen from 4 other bees of both groups were also collected.

182 Secondly, bees were collected from a single bee colony in our experimental apiary where 183 trembling and crawling bees were observed at the hive entrance. Samples of 
184 symptomatic trembling bees were taken from the flight board. The organs from 2 of these 185 bees were dissected and hemolymph collected from 20 other bees. These samples were 186 subjected to the same analyses as the experimentally-infected bee samples.

187 Several categories of adult bees were then sampled i) on the flight board: guards (10), 188 pollen and nectar foragers (10), symptomatic (10) and dead bees (10) and ii) from inside 189 the hive: drones (5), workers on a brood frame (10), workers on a honey frame (20) and 190 emerging bees (5). Pools of pupae (5), larvae (10) and eggs (10) were also sampled.

191

$192 \quad 2.6$ Statistical analysis.

193 The CBPV genomic loads obtained from experimentally- and naturally-infected bees were 194 analysed by the Two sample KS (Kolmogorov-Smirnov) or the Kruskal-Wallis non195 parametric tests using the SYSTAT 9 computer software package (SPSS Inc.). 


\section{Results}

197

$198 \quad 3.1$ Standardisation of the CBPV TaqMan PCR assay

199 The assay was calibrated using a viral RNA control and a plasmid DNA control as

200 standards. The two standard curves generated from the amplification plot of a 10-fold

201 serial dilution (Figure 1) showed a linear correlation between the $C_{\top}$ values and the initial

202 RNA and DNA load over a 7-log range $\left(R^{2}>0.99\right)$. The slopes of the RNA and DNA

203 standard curves were -0.294 and -0.301 respectively, indicating that the efficiency of the

204 CBPV TaqMan PCR was close to $100 \%$, the slope of a linear regression curve being -

2050.303 for a theoretical $100 \%$ effective PCR (SmartCycler user's manual, Instrumentation

206 Laboratory). No amplification was detected in the negative control.

207 The RNA concentration of the positive control, determined by spectrometry, was $2.6 \times$

$20810^{10}$ CBPV RNA copies per $\mu$ l. The estimated CBPV genomic load, according to the RNA

209 and DNA standard curves respectively was $1.14 \times 10^{10}$ and $2.07 \times 10^{10} \mathrm{CBPV}$ copies per

$210 \mu \mathrm{l}$. These results confirm the accuracy of the both standard controls and validate the use

211 of the DNA standard curve for the CBPV TaqMan PCR. The limit of detection of the

212 CBPV TaqMan PCR was 100 CBPV genome equivalent copies, compared to

213 conventional PCR for which the limit of detection of CBPV genome from viral RNA and

214 plasmid DNA control was $10^{4}$ copies (data not shown).

215

$216 \quad 3.2$ Specificity and reproducibility of the CBPV TaqMan PCR

217 CBPV specificity was confirmed by a Blast search on the amplicon (101 bp) generated by

218 the TaqMan PCR. No significant similarity was found.

219 Furthermore, no amplification was detected when this TaqMan PCR was performed on 220 cDNAs obtained from ABPV (Acute bee paralysis virus), SBV (Sacbrood virus), BQCV

221 (Black queen cell virus) or DWV (Deformed wing virus) samples. 
222 The coefficient of variation $(\mathrm{CV})$ of the mean $\mathrm{C}_{\mathrm{T}}$ values obtained for the DNA standard 223 curve ranged from 0.13 to $1.39 \%$ within a run (intra-assay reproducibility) and from 1.21

224 to $2.35 \%$ from run to run (inter-assay reproducibility).

225 The estimated mean CBPV genomic load of the positive control was at $1.43 \times 10^{10} \mathrm{CBPV}$ 226 copies per $\mu$ l of RNA extract, close to the concentration of $2.6 \times 10^{10}$ CBPV RNA copies 227 per $\mu$ l determined by UV spectrometry. The coefficient of variation of $C_{T}$ evaluated from 22810 independent experiments (RNA extraction followed by cDNA synthesis) was $0.99 \%$.

229 The estimated mean CBPV genomic load from field sampled bees was $5.9 \times 10^{4} \mathrm{CBPV}$ 230 copies per bee. The coefficient of variation of $\mathrm{C}_{T}$ evaluated from 10 independent 231 experiments (RNA extraction from homogenized sub-samples followed by cDNA 232 synthesis) was $0.82 \%$. Furthermore, the $\mathrm{C}_{\top}$ results obtained from crushed healthy bees, 233 pre-loaded with purified virus (10 replicates) showed a coefficient of variation of $2.17 \%$.

3.3 Performance of the CBPV TaqMan PCR assay on body segments and tissues of experimentally- and naturally-infected bees

237 The estimated CBPV genomic load in the inoculum applied to the bee thorax was $1.8 \mathrm{x}$ $23810^{8}$ CBPV copies. Few trembling and weakening symptoms were observed 7 to 8 days 239 post-contact in the infected bees group and all bees died 8 to 9 days post-contact. No 240 symptoms occurred in the control group and the survival rate at day 12 was $72 \%$.

241 The CBPV genome equivalent copy numbers (GECN) determined from samples from the 242 infected group are given in Figure 2. The CBPV GECN in samples of mandibular and 243 hypopharyngeal glands, brain and alimentary canal collected from 4 bees ranged from $2443.7 \times 10^{4}$ to $7.2 \times 10^{6}$ copies with respective means of $2.5 \times 10^{5}, 6.8 \times 10^{5}$ and $2.1 \times 10^{6}$ 245 copies. Higher GECN, ranging from $4.4 \times 10^{10}$ to $1.1 \times 10^{12}$ copies, were observed in the 246 dissected organs of the two symptomatic bees sampled from the flight board of the hive. 247 The CBPV GECN in samples of abdomen, thorax and head collected from four other experimentally-infected bees ranged from $1.8 \times 10^{5}$ to $1.9 \times 10^{10}$ copies with respective 249 means of $4.1 \times 10^{8}, 2.4 \times 10^{9}$ and $4.9 \times 10^{9}$ copies. The CBPV genomic load in these 
250 body segment samples was up to $10^{3}$ fold higher than in the dissected tissue samples

251 and this difference was significant $(p=0.018)$. However, no significant difference was

252 observed within the groups.

253 The CBPV genomic loads in hemolymph samples collected from experimentally- and

254 naturally-infected bees were $2 \times 10^{10}$ and $4.1 \times 10^{9}$ copies of CBPV per $\mu$ respectively.

255 No CBPV genomic load was detected in any sample (organs, body sections, or

256 hemolymph) from the control group.

258 3.4 Performance of the CBPV TaqMan PCR assay on various categories of bees 259 sampled from a symptomatic hive

260 The CBPV genomic loads obtained for each category of bees from a hive showing typical 261 symptoms of paralysis are given in Figure 3. The detected CBPV genomic load was 262 significantly higher in guard, symptomatic and dead bees than in drones, foragers, house 263 bees and brood collection $(p<0.001)$. The mean CBPV genomic load in the first category 264 was as high as $10^{12}$ copies per bee, and ranged from $10^{4}$ to $10^{6}$ copies per bee in the 265 second category. No significant difference was observed between guard, symptomatic 266 and dead bees whereas the CBPV GECN in forager bees was significantly different $267(p=0.012)$ to that of house bees sampled from brood and honey frames. The CBPV 268 genomic loads in pupae, larvae and eggs remained relatively low and did not exceed $2 \times$ $26910^{3}$ CBPV copies per individual. 


\section{Discussion}

In this study, a real-time two-step TaqMan RT-PCR assay was developed to quantify the CBPV genomic load in bee samples and determine the distribution of CBPV infection both within the bees and within the hive. A TaqMan probe with primers located in the putative viral RNA polymerase gene of CBPV was used. The standard curves generated with the viral RNA control and with the plasmid containing a partial sequence from the CBPV genome showed that quantitation of this genome was linear over 7 orders of magnitude. The efficiency of both standard curves and their good correlation was confirmed. Quantitation of the positive control from CBPV-infected bee heads gave similar results for both methods compared to the value obtained by UV spectrometry. These results validate the use of the DNA standard curve to quantify CBPV in bee samples. The limit of detection of this TaqMan PCR method was $10^{2}$ CBPV genome equivalent copy number (GECN), representing an improvement of the conventional PCR previously developed in our laboratory (Ribière et al., 2002), for which the limit of detection was $10^{4}$ CBPV copies. The intra-assay and inter-assay reproducibility studies showed the high reproducibility of the method for the standard curve (from $0.13 \%$ to $1.39 \%$ and from $1.21 \%$ to $2.35 \%$ respectively), and for the efficiency of RNA purification and cDNA synthesis from the positive control $(0.99 \%)$. The high reproducibility of the homogenisation technique was validated by the 10 replicates of field samples $(0.82 \%)$ and loaded samples (2.17\%).

CBPV specificity was demonstrated in relation to ABPV (Acute bee paralysis virus), SBV (Sacbrood virus), BQCV (Black queen cell virus) and DWV (Deformed wing virus) samples. These sensitivity, specificity and reproducibility results indicate that this assay can be used to quantify the CBPV genome.

Real-time PCR detection methods have been developed recently for the detection and quantitation of the main honey bee viruses in Varroa destructor (Chantawannakul et al., 2006), or DWV in honey bees and/or Varroa destructor (Chen et al., 2005b; Tentcheva et 
297 al., 2006). This is the first report to describe a real-time PCR detection method for the 298 detection and quantitation of CBPV in honey bees.

299 The performance of our CBPV TaqMan PCR assay was assessed on bees infected by 300 topical application of the virus. Some bees only reproduced trembling symptoms of 301 chronic paralysis during this experiment but all were dead by day 9 post-contact. An 302 infection by intra-thoracic injection was also conducted, as described by Ribiere et al. 303 (2002). In this case, all bees developed trembling symptoms from day 5 post-inoculation. 304 We chose to analyse samples obtained by contact contamination, which corresponds to 305 the supposed natural way of infection. Bailey et al. (1983) showed that CBPV could be 306 transmitted when applied experimentally to the cuticle surface, freshly denuded of its 307 hairs. They hypothesized that the Chronic paralysis virus was transmitted by direct 308 contact with the epidermal cytoplasm and that, in nature, paralysis might be transmitted 309 by contact when healthy bees are crowded with infected individuals.

310 The CBPV quantitative PCR results obtained in this model revealed high genomic loads 311 in the head, thorax and abdomen of infected bees, reaching $1.9 \times 10^{10} \mathrm{CBPV}$ copies in an 312 experimentally-infected bee head. The estimated load in the inoculum was $1.8 \times 10^{8}$ 313 CBPV copies so the CBPV multiplied actively in bees following contact. This corroborates 314 previous works that suggested the existence of a high concentration of CBPV in the head 315 of infected bees (Bailey \& Milne, 1969; Ribière et al., 2002). Although results showed a 316 significant difference between body segments and dissected organs $(p<0.05)$, no 317 significant difference was observed within the two sets of samples. Lower results were 318 found in dissected organs with up to $7.2 \times 10^{6}$ CBPV copies in the alimentary canal of one 319 infected bee. However, higher GECN (up to $1.1 \times 10^{12}$ copies) were revealed in the 320 dissected organs of naturally paralysed bees.

321 Hemolymph samples from experimentally- or naturally-infected bees presented high 322 genomic loads of up to $2 \times 10^{10}$ and $4.1 \times 10^{9}$ CBPV copies per $\mu$ respectively. We 323 confirm the previous observations of Chen et al. (2006) who described CBPV in 324 hemolymph, and demonstrate for the first time the presence of high CBPV loads in this 
tissue. A high CBPV load in the hemolymph of experimentally-infected bees confirms the efficiency of CBPV infestation of bees by topical application. However, the virus loads were higher in the organs of naturally-infected bees than in experimentally-infected bees. We then validated our CBPV TaqMan methodology by conducting a second study in a symptomatic hive in our apiary, that exhibited trembling and crawling bees at the hive entrance. Various categories of bees were analysed to evaluate the CBPV genomic loads and estimate CBPV distribution within the hive.

The results showed that the CBPV genomic load was significantly higher in guard, symptomatic and dead bees (up to $1.9 \times 10^{13}$ CBPV copies) than in forager, drones and workers sampled inside the hive (up to $3.4 \times 10^{6}$ CBPV copies). The results obtained for symptomatic or dead bees confirm the strong correlation between high CBPV genomic load and pathology expression. Surprisingly, the highest CBPV genomic loads were not observed in the oldest bees (the foragers) but in the guard bees, which addresses the question of their role in infection. In fact, the CBPV genomic loads differed significantly between guards and foragers $(p<0.05)$. It could be hypothesized that the high CBPV genomic load detected in guards sampled from the flight board of a highly symptomatic colony might be related to the higher frequency of close contacts of guards, compared to foragers, with other bees. Furthermore, the significantly lower genomic loads observed in drones and house bees sampled inside the hive, compared to forager bees $(p<0.05)$, is in accordance with the fact that the disease is essentially described in older adult bees (Ball, 1999).

The quantitative CBPV PCR results obtained in pupae, larvae and eggs are concordant with the results obtained in brood samples by Chen et al. (2006), who hypothesized the possible transmission of CBPV from the queen to her progeny (Chen et al., 2005a). However, the CBPV genomic load in these various brood samples remained relatively low, and within the limit of sensitivity of our TaqMan CBPV assay. Further investigations on the queen and her progeny will be necessary to more precisely assess the vertical transmission of CBPV and its epidemiological role. 
353 In conclusion, the CBPV TaqMan RT-PCR assay developed in this study provides a 354 sensitive, specific and reproducible method for the quantitation of CBPV genomic RNA. 355 Preliminary assessment of the CBPV genomic loads in bee samples shows that this 356 method can be used to monitor chronic paralysis infection in colonies. Samples of 357 experimentally- and naturally-infected bees were studied during this work. However, 358 CBPV can persist in apparently healthy colonies, without typical symptoms (Bailey et al., 359 1981) and these "non-apparent infections" can be detected by molecular methods 360 (Ribière et al., 2002). CBPV infection should now be studied in parallel in symptomatic 361 and asymptomatic hives to compare the CBPV viral load, and its dynamics and 362 distribution between individuals of the same colony. The question of correlation of the 363 CBPV load threshold with overt disease could then be addressed and, in a broader 364 context, the risk factors associated with the disease. 


\section{ACKNOWLEDGEMENTS}

366 The authors are grateful to Dr. Michel Aubert (AFSSA Sophia Antipolis, France) for his 367 help and valuable comments on the manuscript. We are also grateful to Béatrice 368 Grasland (AFSSA Ploufragan, France) for statistical analysis. This work was supported 369 by the French Ministère de l'Agriculture et de l'Alimentation and by funds from the " 370 Fonds Européens d'Orientation et de Garantie Agricole " (FEOGA), in accordance with 371 the French programme for the improvement of the production and commercialisation of 372 beekeeping products. 


\section{Captions to figures}

\section{$374 \quad$ Figure 1.}

375 RNA and DNA standard curves of CBPV TaqMan PCR assay using a FAM-TAMRA 376 labelled TaqMan probe obtained with a 10 -fold serial dilution $\left(10^{8}-10\right.$ copies) of a viral

377 RNA control from the heads of sick bees (experimentally infected by inoculation) and a $3783.82 \mathrm{~kb}$ plasmid including a $800 \mathrm{bp}$ fragment located in the putative viral RNA polymerase 379 of CBPV, respectively.

380 The standard curves were obtained by linear regression analysis of the $C_{\top}$ measured for 381 each amplification (x-axis) versus the Log copy number for each standard dilution (y382 axis). The slopes of the two standard curves (RNA, -0.294 and DNA, -0.301) and the 383 correlation coefficient are indicated ( $r$-squared $=0.995$ and 0.992 , respectively).

\section{$385 \quad$ Figure 2.}

386 Evaluation of the CBPV genomic load by CBPV TaqMan PCR assay in organ and body 387 contact samples from bees experimentally-infected by contact. The results are expressed 388 as the mean CBPV genome equivalent copy number per organ and body segment 389 collected from bees at 8 to 9 days post-contact. Bars represent the standard deviations.

$391 \quad$ Figure 3.

392 Evaluation of CBPV genomic loads by CBPV TaqMan PCR assay in various categories of 393 bees from a symptomatic hive. The results are expressed as the mean CBPV genome equivalent copy number per bee. Bars represent the standard deviations. 
Figure 1

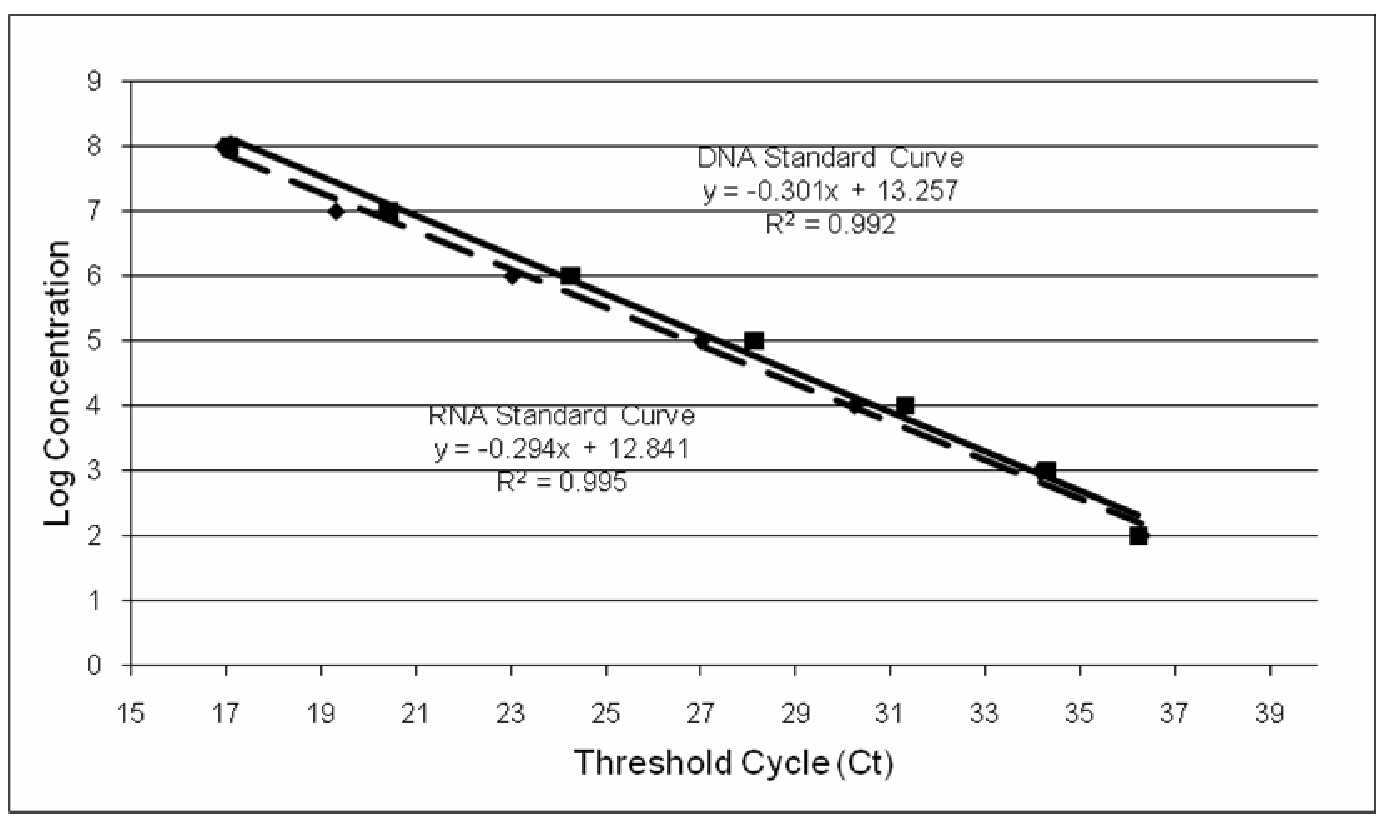

Figure 2

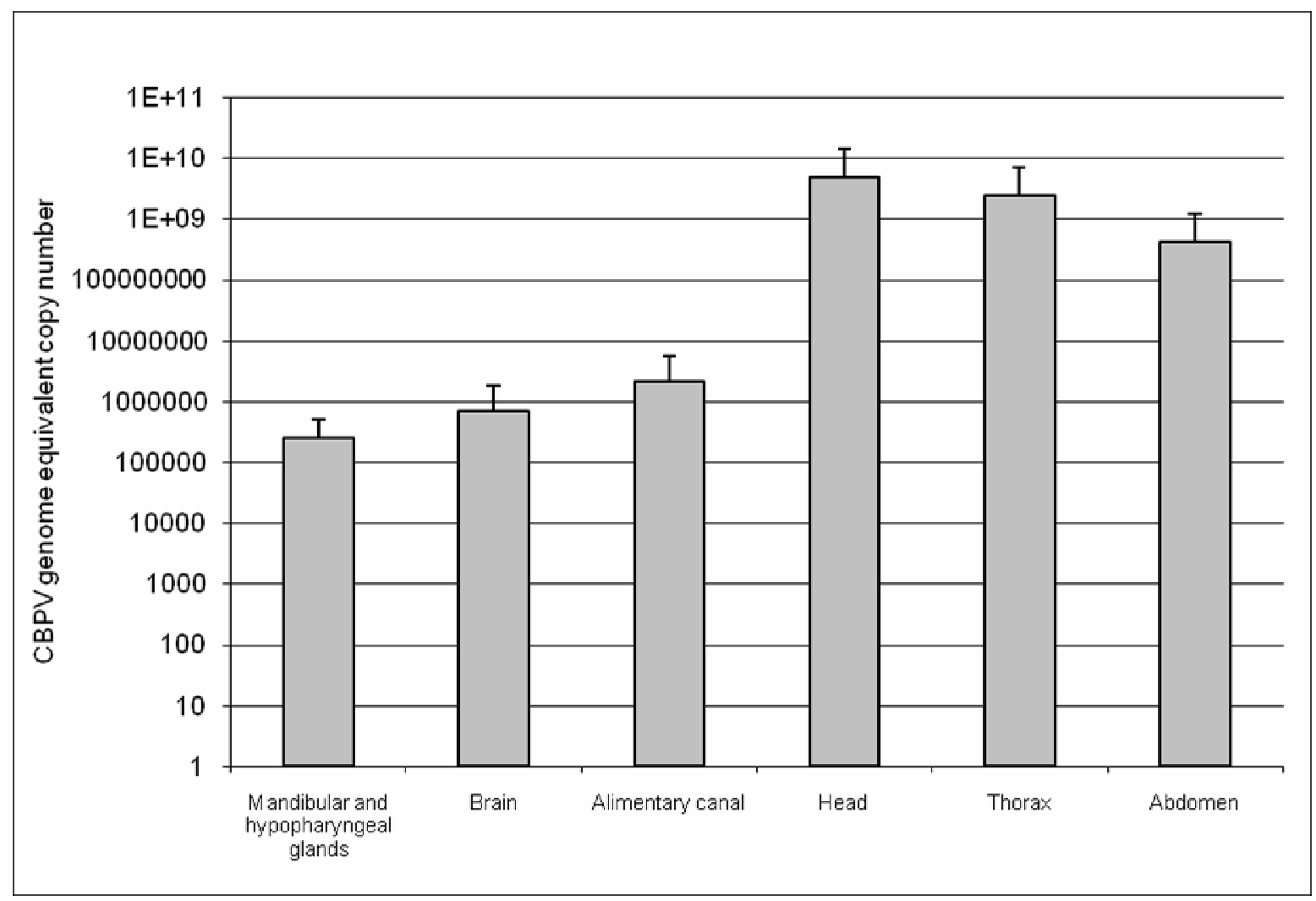




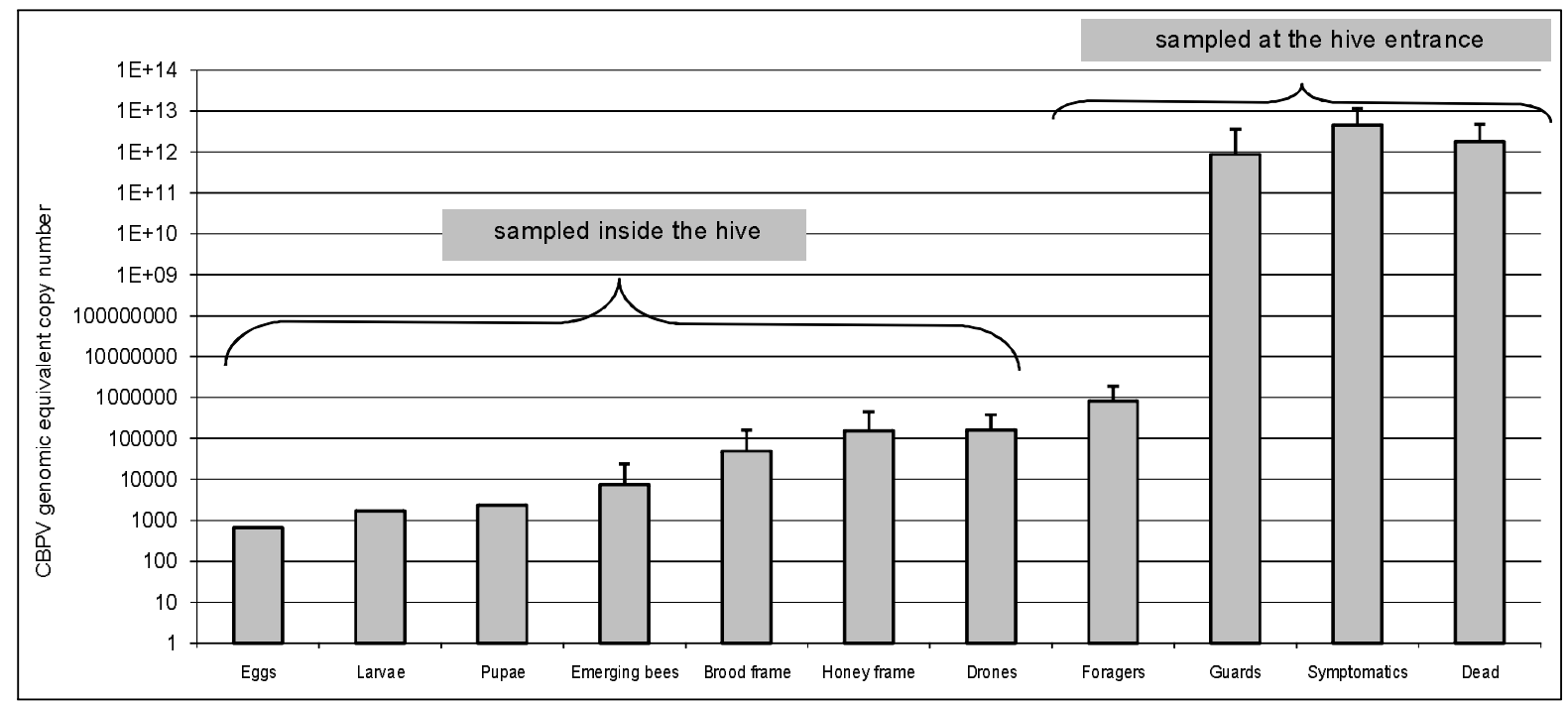

397

398

Reference List

Allen, M., Ball B.V., 1996. The incidence and world distribution of honey bee viruses. Bee World. 77, 141-162.

Bailey, L., Ball, B.V., Perry, J.N., 1981. The prevalence of viruses of honey bees in Britain. Ann.Appl.Biol. 97, 109-118.

Bailey, L., Ball, B.V., Perry, J.N., 1983. Honeybee paralysis: its natural spread and its diminished incidence in England and Wales. J.Apic.Res. 22, 191-195.

Bailey, L.., Gibbs, A.J., Woods, R.D., 1963. Two viruses from adult honey bees (Apis mellifera Linnaeus). Virol. 21, 390-395.

Bailey, L., Gibbs, A.J., Woods, R.D., 1968. The purification and properties of chronic beeparalysis virus. J.Gen. Virol. 2, 251-260.

Bailey, L.., Milne R.G., 1969. The multiplication regions and interaction of acute and chronic bee paralysis viruses in adult honeybees. J.Gen.Virol. 4, 9-14.

Bakonyi, T., Frakas, R., Szendroi, A., Dobos-Kovacs, M., Rusvai, M., 2002. Detection of acute bee paralysis virus by RT-PCR in honey bee and Varroa destructor field samples: rapid screening of representative Hungarian apiaries. Apidologie 33, 63-74.

Ball, B.V., 1999. Paralysis. In Bee disease diagnosis. Eds M.E.Colin, B.V.Ball \& M.Kilani. Options Mediterannéennes. pp. 81-89. 
Ball, B.V., Bailey, L., 1997. Viruses. In Honey bee pests, predators, \& diseases. Third edition Ed. Eds R.A.Morse \& K.Flottum. Medina: A.I. Root Company. pp. 11-32.

Chantawannakul, P., Ward, L., Boonham, N., Brown, M., 2006. A scientific note on the detection of honeybee viruses using real-time PCR (TaqMan) in Varroa mites collected from a Thai honeybee (Apis mellifera) apiary. J.Invertebr.Pathol. 91, 69-73.

Chen, Y., Pettis, J.S., Feldlaufer, M.F., 2005a. Detection of multiple viruses in queens of the honey bee Apis mellifera L. J.Invertebr.Pathol. 90, 118-121.

Chen, Y.P., Higgins, J.A., Feldlaufer, M.F., 2005b. Quantitative Real-Time Reverse Transcription-PCR Analysis of Deformed Wing Virus Infection in the Honeybee (Apis mellifera L.). Appl.Environ.Microbiol. 71, 436-441.

Chen, Y.P., Pettis, J.S., Collins, A., Feldlaufer, M.F., 2006. Prevalence and transmission

Fluri, P., Lüscher, M., Wille, H., Gerig, L., 1982. Changes in weight of the pharyngeal gland and haemolymph titres of juvenile hormone protein and vitellogenin in worker honey bees. J.Insect Physiol. 28, 61-68.

Grabensteiner, E., Ritter, W., Carter, M.J., Davison, S., Pechhacker, H., Kolodziejek, J., Boecking, O., Derakhshifar, I., Moosbeckhofer, R., Licek, E., Nowotny, N., 2001. Sacbrood virus of the honeybee (Apis mellifera): rapid identification and phylogenetic analysis using reverse transcription-PCR.Clin.Diagn.Lab.Immunol. 8, 93-104.

Heid, C.A., Stevens, J., Livak, K.J., Williams, P.M., 1996. Real time quantitative PCR. Genome Res 6, 986-94.

Hoolland, P.M., Abramson, R.D., Watson, R., Gelfand, D.H., 1991. Detection of specific polymerase chain reaction product by utilizing the 5'----3' exonuclease activity of Thermus aquaticus DNA polymerase. Proc Natl Acad Sci U S A 88, 7276-80.

Livak, K.J., Flood, S.J., Marmaro, J., Giustoi, W., Deetz, K., 1995. Oligonucleotides with fluorescent dyes at opposite ends provide a quenched probe system useful for detecting PCR product and nucleic acid hybridization. PCR Methods Appl 4, 357-62.

Ribière, M., Faucon, J.P., Pépin, M., 2000. Detection of chronic bee paralysis virus infection: application to a field survey. Apidologie $31,567-577$.

Ribière, M., Triboulot, C., Mathieu, L., Aurières, C., Faucon, J.P., Pépin, M., 2002. Molecular diagnosis of chronic bee paralysis virus infection. Apidologie 33, 339-351.

Tentcheva, D., Gauthier, L., Bagny, L., Fievet, J., Dainat, B., Cousserans, F., Colin, M.E., Bergoin, M., 2006. Comparative analysis of deformed wing virus (DWV) RNA in Apis mellifera and Varroa destructor. Apidologie 37, 41-50. 